\title{
Recombinant $\alpha-\mathrm{N}-$ Acetylgalactosaminidase from Marine Bacterium-Modifying A Erythrocyte Antigens
}

\author{
L. A. Balabanova ${ }^{1,2^{*}}$, V. A. Golotin ${ }^{1}$, I. Y. Bakunina ${ }^{1}$, L. V. Slepchenko ${ }^{1}$, V. V. Isakov ${ }^{1}$, \\ A. B. Podvolotskaya², V. A. Rasskazov ${ }^{1}$ \\ ${ }^{1}$ G.B. Elyakov Pacific Institute of Bioorganic Chemistry, Far Eastern Branch, Russian Academy of \\ Sciences, 100-letiya Vladivostoka Ave., 159, 690022, Vladivostok, Russia \\ ${ }^{2}$ Far Eastern Federal University, Sukhanova Str., 8, 690950, Vladivostok, Russia \\ *E-mail: balaban@piboc.dvo.ru \\ Received 14.11.2014 \\ Copyright @ 2015 Park-media, Ltd. This is an open access article distributed under the Creative Commons Attribution License, which permits \\ unrestricted use, distribution, and reproduction in any medium, provided the original work is properly cited.
}

\begin{abstract}
A plasmid based on pET-40b was constructed to synthesize recombinant $\alpha-N$-acetylgalactosaminidase of the marine bacterium Arenibacter latericius KMM $426^{\mathrm{T}}(\boldsymbol{\alpha}-\mathbf{A l N a G a l})$ in Escherichia coli cells. The yield of $\boldsymbol{\alpha}$-Al$\mathrm{NaGal}$ attains $10 \mathrm{mg} / \mathrm{ml}$ with activity of $49.7 \pm 1.3 \mathrm{U}$ at $16^{\circ} \mathrm{C}$, concentration of inductor $2 \mathrm{mM}$, and cultivation for $12 \mathrm{~h}$. Techniques such as anion exchange, metal affinity and gel filtration chromatography to purify $\alpha$ - $A l \mathrm{NaGal}$ were applied. $\alpha-A l \mathrm{NaGal}$ is a homodimer with a molecular weight of $164 \mathrm{kDa}$. This enzyme is stable at up to $50^{\circ} \mathrm{C}$ with a temperature range optimum activity of $20-37^{\circ} \mathrm{C}$. Furthermore, its activity is independent of the presence of metal ions in the incubation medium. ${ }^{1} \mathrm{H}$ NMR spectroscopy revealed that $\alpha-A l N a G a l$ catalyzes the hydrolysis of the $\mathrm{O}$-glycosidic bond with retention of anomeric stereochemistry and possesses a mechanism of action identical to that of other glycoside hydrolases of the 109 family. $\alpha-A l \mathrm{NaGal}$ reduces the serological activity of $\mathrm{A}$ erythrocytes at $\mathrm{pH}$ 7.3. This property of $\alpha-A l \mathrm{NaGal}$ can potentially be used for enzymatic conversion of $\mathrm{A}$ and $\mathrm{AB}$ erythrocytes to blood group $O$ erythrocytes.
\end{abstract}

KEYWORDS glycoside hydrolase GH109; Arenibacter latericius; ${ }^{1} \mathbf{H}$ NMR spectroscopy; conversion of A erythrocytes.

\section{INTRODUCTION}

$\alpha-\mathrm{N}$-Acetylgalactosaminidases (EC 3.2.1.49) catalyze the removal of 2-acetamido-2-deoxy- $D$-glucopyranosyl residues bound via the $\alpha$-O-glycosidic bond (GalNAc $\alpha$ ) from the non-reducing ends of oligosaccharides and glycoconjugates: in particular agglutinogens of the human blood groups A and AB. $\alpha-\mathrm{N}$-Acetylgalactosaminidases can be used to study the structure of natural compounds and synthesize new oligosaccharides [1]. The study of $\alpha-\mathrm{N}$-acetylgalactosaminidases is also associated with their involvement in the catabolism of complex oligosaccharides in the human body [2]. The practical interest in the enzyme has stemmed from the fact that it can potentially be used for enzymatic conversion of the blood groups $\mathrm{A}$ and $\mathrm{AB}$ to the universal blood group $\mathrm{O}$ via deglycosylation of antigenic determinants [3]. For this purpose, glycoside hydrolases of family 27 (GH27) from chicken liver and family 36 (GH36) from Clostridium perfringens bacterium were isolated $[4,5]$. These enzymes have a number of disadvantages for biotechnological application, such as an unphysiological $\mathrm{pH}$ optimum and inefficiency in converting erythrocytes of subtype $\mathrm{A}_{1}$.

$\alpha-\mathrm{N}$-Acetylgalactosaminidase of Arenibacter latericius $\mathrm{KMM} 426^{\mathrm{T}}$, which effectively inactivates the serological activity of the $A_{1}$ and $A_{2}$ antigens of erythrocytes at neutral $\mathrm{pH}$, was discovered by screening 3,000 strains of marine bacteria [6, 7]. Based on the classification of structural homology, $\alpha-\mathrm{N}$-acetylgalactosaminidase of Arenibacter latericius KMM $426^{\mathrm{T}}$ is classified as belonging to the glycoside hydrolase family 109 (GH109) [8, 9].

A method for synthesizing recombinant $\alpha-\mathrm{N}$-acetylgalactosaminidase ( $\alpha-A l N a G a l)$ to study its enzymatic properties is suggested in this work.

The nucleotide sequence of the $\alpha-A l \mathrm{NaGal}$ gene was amplified from the genomic DNA of marine bacterium A. latericius type strain KMM $426^{\mathrm{T}}$ using primers: Nac40_NcoF (5'-TTAACCATGGAAAATCTTTATTTTCAGGGTGGGGCTAAGTACA TGGGCGGTTTTTCTGCT-3') and Nac40_SalIR (5'-TTAAGTCGACACCCTGAAAATAAAGATTTTCGCTTA- 
CAATATCTAATGGTGCAGTGGT-3') (Eurogene). PCR amplification was performed in an Eppendorf amplifier using the following program: $95^{\circ} \mathrm{C}$ for 2 min and 35 cycles of $95^{\circ} \mathrm{C}$ for $15 \mathrm{~s}, 72^{\circ} \mathrm{C}$ for $1 \mathrm{~min}$. The $\alpha-A l \mathrm{NaGal}$ gene was cloned into vector pET-40b(+) (Novagen) at the NcoI-SalI restriction sites after the DsbC sequence and His-tag. Recombinant plasmids were obtained in Escherichia coli $\mathrm{DH} 5 \alpha$ cells. The $\alpha-A l \mathrm{NaGal}$-producing strain was obtained by transformation of plasmid into E. coli Rosetta(DE3). An overnight culture of the producing strain was grown in a 1-l flask with a liquid LB medium ( $\mathrm{pH} 7.7$ ) containing $25 \mathrm{mg} / \mathrm{ml}$ of kanamycin at $37^{\circ} \mathrm{C}$ and shaking at $200 \mathrm{rpm}$. When the culture reached the $\mathrm{OD}_{600}$ of $0.6-0.8$, it was induced with $0.2 \mathrm{mM}$ isopropyl- $\beta-D-1$-thiogalactopyranoside (IPTG) and incubated at $16^{\circ} \mathrm{C}$ for $12 \mathrm{~h}$.

Activity of $\alpha-A l \mathrm{NaGal}$ was determined according to the cleavage of $p$-nitrophenyl- $\alpha-\mathrm{N}$-acetylgalactosaminide. The reaction mixture $(400 \mu \mathrm{l})$ contained $10 \mathrm{mM} \mathrm{NaH}_{2} \mathrm{PO}_{4}, \mathrm{pH} 7.2,3 \mathrm{mM}$ substrate, and the enzyme. After $20 \mathrm{~min}$ of incubation at $20^{\circ} \mathrm{C}$, the reaction was terminated by adding $0.6 \mathrm{ml}$ of $1-\mathrm{Ml} \mathrm{Na}_{2} \mathrm{CO}_{3}$. $\mathrm{Ab}-$ sorbance at $400 \mathrm{~nm}$ was used to calculate the amount of the released product. One unit of activity (U) was defined as the amount of enzyme catalyzing the formation of $1 \mu \mathrm{M}$ of $p$-nitrophenol per minute. Specific activity was estimated as units of enzyme activity per milligram of the protein. Protein concentration was determined according to the Bradford method. The yield of the total enzyme activity was $49.7 \pm 1.3 \mathrm{U}$ per $1 \mathrm{l}$ of culture broth.

Purification of $\alpha-A l \mathrm{NaGal}$ was carried out at $+6^{\circ} \mathrm{C}$. $E$. coli cells were centrifuged at 5,000 rpm for $10 \mathrm{~min}$, re-suspended in $200 \mu \mathrm{l}$ of buffer A $\left(0.01 \mathrm{M} \mathrm{NaH}_{2} \mathrm{PO}_{4}\right.$, $\mathrm{pH} 7.8,0.01 \% \mathrm{NaN}_{3}$ ), and sonicated using a UZDN 2-T ultrasonic disperser (USSR). The solution was centrifuged (25 min, 11,000 rpm) and added to the column $(2.5 \times 37 \mathrm{~cm})$ containing a DEAE-MacroPrep ion exchange resin (Bio-Rad) equilibrated with buffer A. Elution was performed with a linear gradient of $0-0.25$ $\mathrm{M} \mathrm{NaCl}$ in buffer $\mathrm{A}$. The active fractions were collected and loaded onto a column $(1 \times 2 \mathrm{~cm})$ with $\mathrm{Ni}$-agarose (Qiagen). The protein was eluted using $50 \mathrm{mM}$ EDTA. The eluate was loaded onto a Sephacryl S-200HR (Sigma) gel filtration column equilibrated with buffer $\mathrm{A}$. Homogeneity of $\alpha-A l \mathrm{NaGal}$ was confirmed using a $12 \%$ polyacrylamide gel in the presence of sodium dodecyl sulfate (SDS-PAGE) (Fig. 1). The results of gel filtration revealed that $\alpha-A l \mathrm{NaGal}$ is a homodimer with a molecular weight of $164 \mathrm{kDa}(96 \mathrm{kDa}$ after $\mathrm{DsbC}$ plasmid sequence at the site of enterokinase (Novagen) had been removed). The enzyme is stable at up to $50^{\circ} \mathrm{C}$ with a temperature range of optimum activity of $20-37^{\circ} \mathrm{C}$, while its activity is independent of the

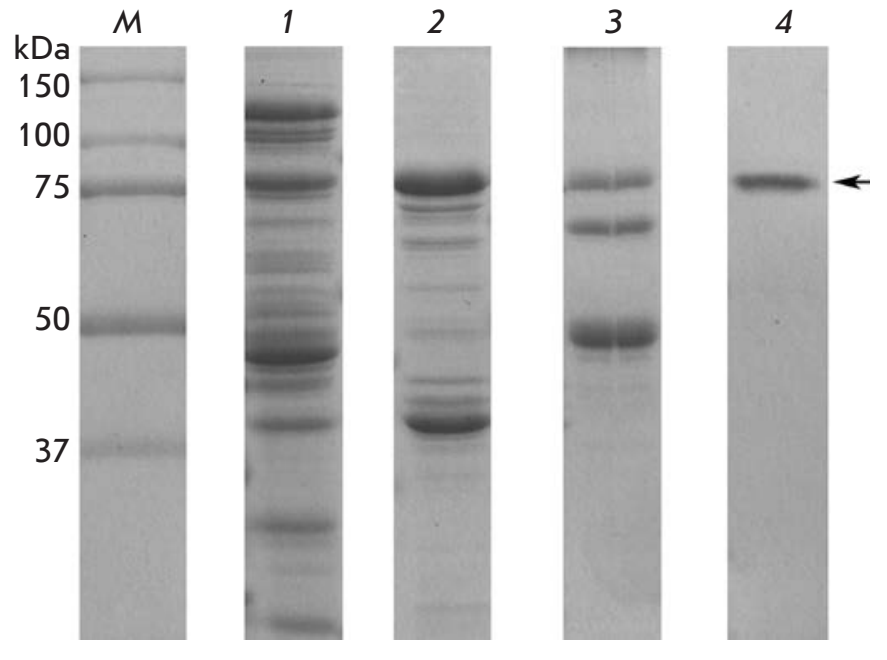

Fig. 1. The expression and purification of $\alpha-A N a G a l$ ( $12 \%$ SDS-PAGE): $M$ - protein molecular weight marker (Bio-Rad); 1 -whole-cell extract; 2 -DEAE-MacroPrep; 3 - Ni-agarose; 4 - Sephacryl S-200HR. Migration of $\alpha-A l-$ $\mathrm{NaGal}$ is marked with an arrow

presence of metal ions in the incubation medium. The additional amino acid residues have no influence on the enzymatic properties; therefore, their removal can be neglected. The optimum $\mathrm{pH}$ was determined in 20 $\mathrm{mM} \mathrm{Na}{ }^{+}$-phosphate and glycine- $\mathrm{NaOH}$ buffers at intervals of pH 5.4-8.2 and 8.0-10.0 (Fig. 2A). The study of the $\alpha-A l \mathrm{NaGal}$ properties revealed a possibility of usage to deglycosylate blood group A erythrocyte determinants (blood transfusion station, Vladivostok) at neutral $\mathrm{pH}$. Blood group A erythrocytes were washed with a normal saline solution and then diluted with a $\mathrm{Na}^{+}$-phosphate isotonic buffer to a final concentration of $20 \% .0 .02 \mathrm{ml}$ of the obtained suspension was mixed with $0.08 \mathrm{ml}$ of the $\alpha-A l \mathrm{NaGal}$ solution $(0.004 \mathrm{U})$ in the same buffer. After $24 \mathrm{~h}$ of incubation at $26^{\circ} \mathrm{C}$, erythrocytes were washed three times using the same buffer ( $\mathrm{pH}$ 7.3) with gentle shaking. A $1 \%$ suspension was prepared and then mixed with an anti-A serum (Mediclon, Russia) in a series of double-dilution steps in 96well plates (Costar). After $1 \mathrm{~h}$ of incubation at room temperature, agglutination titer was measured (Fig. $2 B$ ). The results of an immunological analysis showed that the serological activity of A antigens of erythrocytes treated with $\alpha-A l \mathrm{NaGal}$ decreases as a result of their enzymatic transformation to $\mathrm{H}$ antigens, because no agglutination was observed up to a titer of $1 / 16$. $\alpha-A l N a G a l$ causes neither nonspecific aggregation of erythrocytes nor their hemolysis.

The enzyme of marine bacterium Arenibacter latericius type strain KMM $426^{\mathrm{T}}$ can fully inactivate the se- 
A
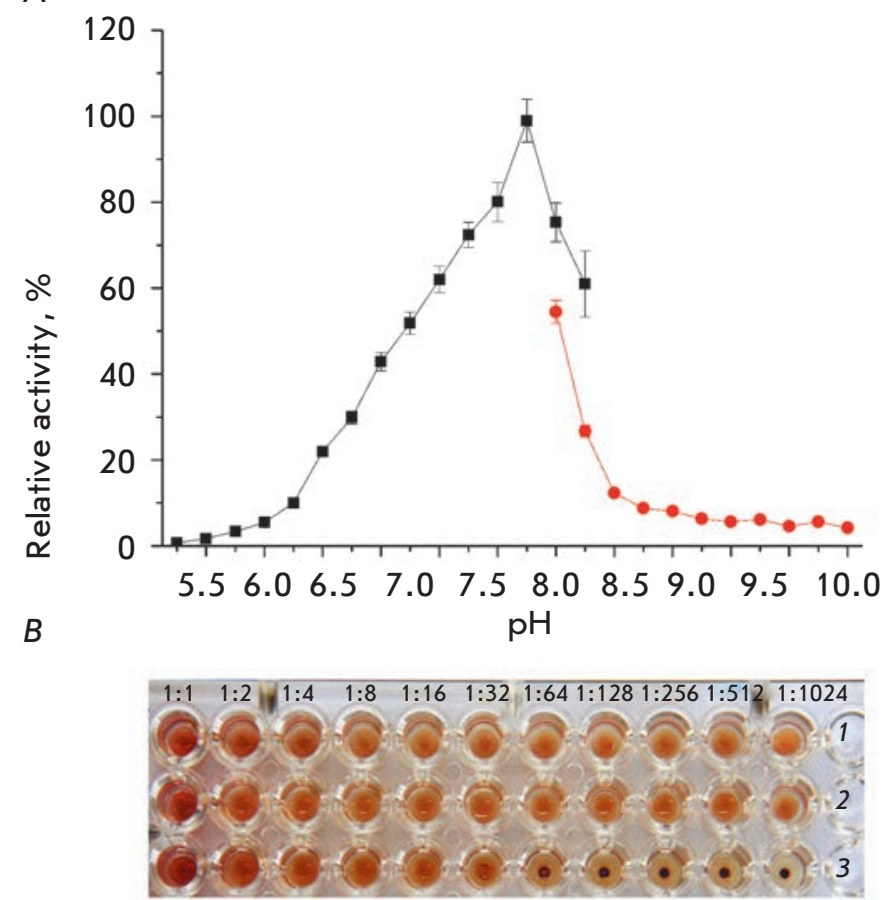

Fig. 2. Enzymatic properties of $\alpha-A \mathbb{N a G a l :} \mathbf{A}$ - optimum $\mathrm{pH}$ of $\alpha-A \mathbb{N a G a l}$; $\mathbf{B}-1 \%$ suspension of $A$ erythrocytes mixed with anti-A serum in a series of double-dilution steps in: 1 - $20 \mathrm{mM} \mathrm{Na}^{+}$-phosphate buffer, 2-20 $\mathrm{mM}$ glycine- $\mathrm{NaOH}$ buffer, $3-20 \mathrm{mM} \mathrm{Na}{ }^{+}$-phosphate buffer after treatment with $\alpha-A \mathbb{N a G a l}$

rological activity of $\mathrm{A}$ erythrocytes at neutral $\mathrm{pH}$ and compares favorably with $\alpha-\mathrm{N}$-acetylgalactosaminidases from chicken liver and $C$. perfringens, which affect only the $\mathrm{A}_{2}$ subgroup of erythrocytes [5, 6]. Being classical hydrolases, the GH27 and GH36 enzymes catalyze the hydrolysis of the O-glycosidic bond of their substrate via the double displacement mechanism with retention of the stereochemistry of the anomeric center of the substrate [10]. More recently, an enzyme of a new GH109 family has been isolated from pathogenic bacterium Elizabethkingia meningoseptica. This enzyme had properties similar to those of $\alpha-\mathrm{N}$-acetylgalactosaminidase of the A. latericius type strain $\mathrm{KMM} 426^{\mathrm{T}}$ and a different mechanism of hydrolysis of the classical hydrolases [8]. The mechanism includes stages of elimination of the O-glycosidic bond and proton exchange at $\mathrm{C} 2$ of $\mathrm{N}$-acetylgalactosamine with retention of anomeric stereochemistry.

The configuration of the anomeric center of the hydrolysis products of $\alpha-A l \mathrm{NaGal}$ was directly examined using ${ }^{1} \mathrm{H}$ NMR spectroscopy. The experiment was carried out at $20^{\circ} \mathrm{C}$ using a DRX-500 NMR spectrometer
A

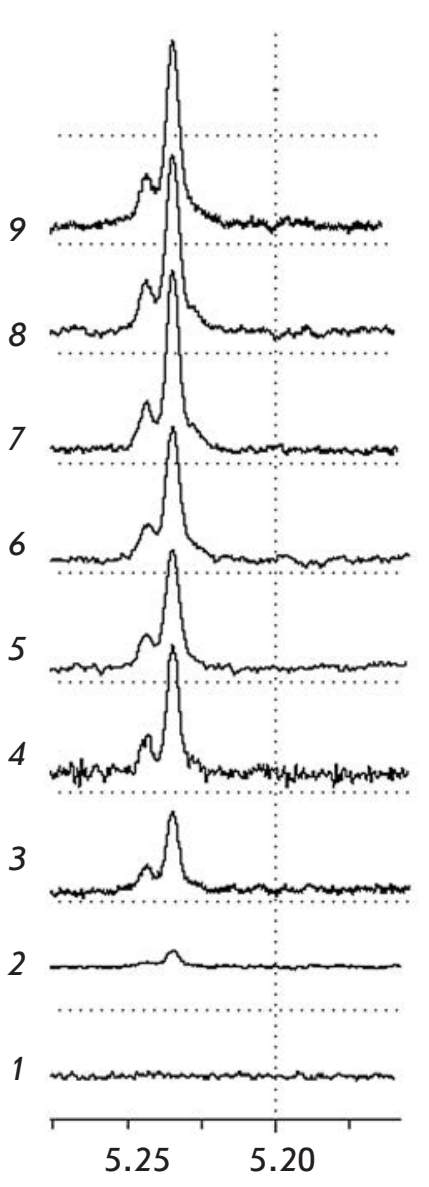

$B$

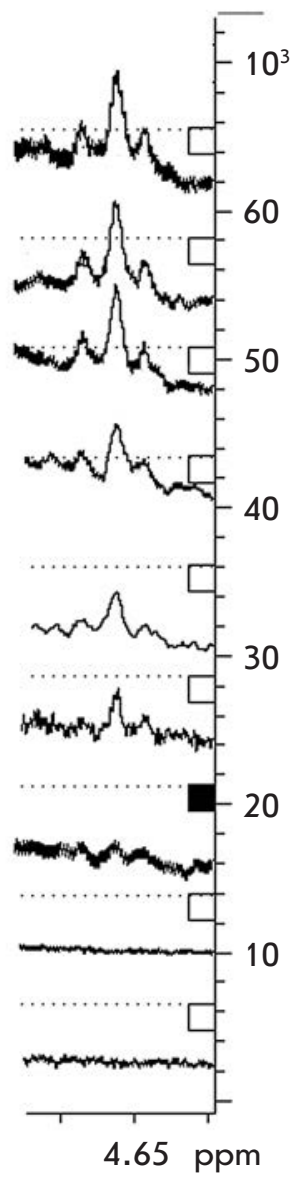

Fig. 3. The resonance regions $\Delta \delta=5.30-5.20 \mathrm{ppm}(\mathbf{A})$ and $\Delta \delta=4.75-4.10 \mathrm{ppm}$ (B) of ${ }^{1} H$ NMR spectrum of $\alpha$ - and $\beta$-anomeric atoms of $\mathrm{N}$-acetylgalactosamine as a product of $\alpha-A \mathbb{N a G a}$ hydrolysis for $0 \mathrm{~min}(1), 10 \mathrm{~min}(2), 20 \mathrm{~min}$ (3), $30 \mathrm{~min} \mathrm{(4),} 40 \mathrm{~min}$ (5), $50 \mathrm{~min}$ (6), $80 \mathrm{~min}$ (7), $90 \mathrm{~min}$ (8), $100 \min (9)$

(Bruker). ${ }^{1} \mathrm{H}$ NMR spectra were acquired using a spectral width of $5,000 \mathrm{~Hz}$ over 32,000 data points. Prior to the analysis, $0.6 \mathrm{ml}$ of a $50 \mathrm{mM} \mathrm{Na}{ }^{+}$-phosphate solution ( $\mathrm{pH} 7.5$ ) containing $6.0 \mathrm{mM} p$-nitrophenyl- $\alpha-\mathrm{N}$-acetylgalactosaminide substrate was evaporated and dissolved in $0.6 \mathrm{ml}$ of $\mathrm{D}_{2} \mathrm{O}$. The deuterium-exchanged $\alpha-A l N a G a l$ was obtained using Vivaspin turbo $10 \mathrm{k}$ MWCO columns (Sartorius). Chemical shifts in spectra were referenced to acetone $(\delta=2.22 \mathrm{ppm})$ in $\mathrm{D}_{2} \mathrm{O}$ used as an external standard. After measuring the initial spectra of the substrate at $t=0 \mathrm{~min}, 0.1 \mathrm{ml}$ of the deuterium-exchanged $\alpha-A l \mathrm{NaGal}$, containing 0.98 $\mathrm{U}$, was added to $6.0 \mathrm{mM}$ of the deuterium-exchanged $p$-nitrophenyl- $\alpha-\mathrm{N}$-acetylgalactosaminide in $0.6 \mathrm{ml}$ $\mathrm{D}_{2} \mathrm{O}$ to initiate the reaction. The ${ }^{1} \mathrm{H}$ NMR spectra were 
automatically recorded at $10 \mathrm{~min}$ intervals for $180 \mathrm{~min}$ after the onset of the reaction. Figure 3 shows the resonance regions $\Delta \delta=5.30-5.20 \mathrm{ppm}$ and $\Delta \delta=4.75-4.10$ ppm of the ${ }^{1} \mathrm{H}$ NMR spectrum of the reaction products. The product, with a resonance signal at $5.22 \mathrm{ppm}$, is formed during the first minutes after enzyme addition (Fig. 3A). This signal corresponds to the proton of the anomeric center of unbound $\mathrm{N}$-acetylgalactosamine $($ GalNAc $\alpha$ ). Signal intensity increases during the following $10 \mathrm{~min}$ of the reaction. The signal of the $\beta$-anomer of GalNAc $\alpha$ with the chemical shift at $4.64 \mathrm{ppm}$ as a result of mutarotation appears only after 20 min of the reaction's onset (Fig. 3B). The spectra of $\alpha$ - and $\beta$-anomers of unbound GalNAc $\alpha$ show that the signals are observed as doublets with SSCC of 3.8 and $7.8 \mathrm{~Hz}$, and a singlet. These observations indicate that proton-deuterium substitution takes place at C2. Such a catalytic mechanism is typical of glycoside hydrolases GH109 [8, 11].

\section{CONCLUSIONS}

The recombinant protein $\alpha-A l \mathrm{NaGal}$ with a molecular weight of $164 \mathrm{kDa}$, with the properties of $\alpha-\mathrm{N}$-acetylgalactosaminidase of marine bacterium $A$. latericius type strain KMM $426^{\mathrm{T}}$, was synthesized. $\alpha-A l \mathrm{NaGal}$ catalyzes the hydrolysis of the $\alpha-\mathrm{O}$-glycosidic bond with retention of the stereochemistry of the anomeric center of the substrate and proton exchange to deuterium of the solvent at $\mathrm{C} 2$ via a mechanism typical of glycoside hydrolases of the GH109 family. $\alpha-A l \mathrm{NaGal}$ deglycosylates A antigens of the blood at $\mathrm{pH}$ 7.5. This property demonstrates that $\alpha-A l \mathrm{NaGal}$ can be used to obtain blood group $\mathrm{O}$ erythrocytes.

This work was supported by the Russian Foundation for Basic Research (grant № 13-04-00806) and the Scientific Foundation of the Far Eastern Federal University (14-08-06-10_i).

\section{REFERENCES}

1. Vallée F., Karaveg K., Herscovics A., Moremen K.W., Howell P.L. // J. Biol. Chem. 2000. V. 275. № 52. P. 41287-41298.

2. Keulemans J.L.M., Reuser A.J.J., Kroos M.A., Willemsen R., Hermans M.M.P., van den Ouweland A.M.W., de Jong J.G.N., Wevers R.A., Renier W.O., Schindler D., et al. // J. Med. Genet. 1996. V. 33. № 6. P. 458-464.

3. Olsson M.L., Hill C.A., de laVega H., Liu Q.P., Stroud M.R., Valdinocci J., Moon S., Clausen H., Kruskall M.S. // Transfus. Clin. Biol. 2004. V. 11. № 1. P. 33-39.

4. Hata J., Dhar M., Mitra M., Harmata M., Haibach P., Sun P., Smith D. // Biochem. Int. 1992. V. 28. № 1. P. 77-86.

5. Hsieh H.Y., Smith D. // Biotechnol. Appl. Biochem. 2003. V. 37. № 2. P. 157-163.

6. Ivanova E.P., Bakunina I.Y., Nedashkovskaya O.I., Gorshkova N.M., Mikhailov V.V., Elyakova L.A. // Marine Biology
(Russian). 1998. V. 24. № 6. P. 351-358.

7. Bakunina I.Y., Kulman R.A., Likhosherstov L.M., Martynova M.D., Nedashkovskaya O.I., Mikhailov V.V., Elyakova L.A. //Biochemistry (Russian). 2002. V. 67. № 6. P. 830-837.

8. Liu Q.P., Sulzenbacher G., Yuan H., Bennett E.P., Pietz G., Saunders K., Spence J., Nudelman E., Levery S.B., White T., et al. // Nat. Biotechnol. 2007. V. 25. № 4. P. 454-464.

9. Bakunina I., Nedashkovskaya O., Balabanova L., Zvyagintseva T., Rasskazov V., Mikhailov V. // Mar. Drugs. 2013. V. 11. P. 1977-1998.

10. Comfort D.A., Bobrov K.S., Ivanen D.R., Shabalin K.A., Harris J.M., Kulminskaya A.A., Brumer H., Kelly R.M. // Biochemistry. 2007. V. 46. № 11. P. 3319-3330.

11. Chakladar S., Abadib S.S.K., Bennet A.J. // Med. Chem. Commun. 2014. V. 5. P. 1188. 